\title{
GEMİ YAPIMINDA KULLANILAN AHŞAP MALZEMELERDE OLUŞAN BİYOFILM VE FOULİNG
}

\author{
Zübeyde BÜLBÜL1* ${ }^{*}$ Nurdan FíLİK \\ ${ }^{1}$ İstanbul Üniversitesi-Cerrahpaşa, Ormancllık Meslek Yüksekokulu, Malzeme ve Malzeme İşleme Teknolojileri \\ Bölümü, 34473 Bahçeköy Sarıyer, İstanbul, Türkiye \\ ${ }^{2}$ Isparta Uygulamalı Bilimler Üniversitesi, Eğirdir Su Ürünleri Fakültesi, 32260, Isparta, Türkiye
}

\begin{tabular}{|c|c|}
\hline Anahtar Kelimeler & Öz \\
\hline $\begin{array}{l}\text { Biyofilm, } \\
\text { Ahşap gemi malzemesi, } \\
\text { Fouling, } \\
\text { Mikroorganizma. }\end{array}$ & $\begin{array}{l}\text { Bu çalışmada; ağaç malzemeden yapılan gemi, tekne, yat gibi suyla temas eden odun } \\
\text { materyalinin zamanla üzerinde oluşan, biyofilm (mikrop tabakası), fouling (kirlenme), } \\
\text { biyofouling (biyolojik kirlenme) tabakaları anlatılısıstır. Bunun yanı sıra ahşap gema } \\
\text { yapımında tercih edilen ağaç türleri ve suyla temas eden ahşap yüzeyinde oluşan } \\
\text { mikroorganizmalar ve biyofilm üzerinde durulmuştur. Biyofilm oluşumu beraberinde } \\
\text { orada bulunan bakterilerin virülens gücü gemi personelinin sağlığını kötü yönde } \\
\text { etkileyecektir ve aynı zamanda ahşap materyali korozyona uğratarak mali anlamda da } \\
\text { zarar oluşturacaktır. Bu nedenle biyofilm, fouling, biyofouling oluşumların engellenmesi } \\
\text { gemi endüstrisi açısından önem arz etmektedir. Ahşap seçiminde bütün bu doğa } \\
\text { tahribatına karşı dayanıklılık esas alınmalıdır. Tekne yapımında kullanılan ağaç malzeme } \\
\text { maruz kaldığı hızlı adaptasyonu, higroskopik özelliği, bünyesinde bulundurması gereken } \\
\text { nem oranı ve direnç özelliklerine göre belirlenip çalışmanın piyasada rehber olması } \\
\text { öngörülmüștür. Bu araştırmada gemi yapımında en uygun ahşap malzemelerin tespitine } \\
\text { yardımcı olmak amaçlanmıștır. }\end{array}$ \\
\hline
\end{tabular}

\section{BIOFILM AND FOULING IN WOOD MATERIALS USED IN SHIP CONSTRUCTION}

\begin{tabular}{l}
\hline Keywords \\
Biofilm, \\
Wooden ship material, \\
Fouling, \\
Microorganism.
\end{tabular}

Microorganism.

\begin{abstract}
In this study; biofilm (city of microsphere), fouling (pollution), biofoiling (biological pollution) that occurs over time, on the wood material contact with water such as a ship, boat, yacht made from wood material, layers are described. This study, focused on wood species preferred for wooden ship construction and microorganisms and biofilm formed on the wood surface in contact with water. The formation of biofilm and the presence of virulence will affect the health of the ship's personnel in the worst way and at the same time it will corrode the wood material and cause financial damage. Therefore, prevention of biofilm, fouling, biofouling formation are important for ship industry. The choice of wood should be based on the resistance to against all this natural destruction. Rapid adaptation of wood material used in boat construction, hygroscopic property, moisture content that need to keep within, determined by resistance properties, predicted that this work will be a guide in the market. This research, aimed to help determine the most suitable wood materials for ship building.
\end{abstract}

\section{Alıntı / Cite}

Bülbül Z., Filik N., (2019). Gemi Yapımında Kullanılan Ahşap Malzemelerde Oluşan Biyofilm ve Fouling, Mühendislik Bilimleri ve Tasarım Dergisi, 7(1), 1-6.

Yazar Kimliği / Author ID (ORCID Number)

Z. Bülbül - 0000-0003-2017-8407

N. Filik - 0000-0003-4376-7298

Makale Süreci / Article Process

Başvuru Tarihi / Submission Date $\quad$ 27.02.2018

Revizyon Tarihi / Revision Date $\quad$ 03.09.2018

Kabul Tarihi / Accepted Date $\quad$ 19.09.2018

Yayım Tarihi / Published Date $\quad 25.03 .2019$

\footnotetext{
* Ilgili yazar / Corresponding author: zubeyde.bulbul@istanbul.edu.tr, +90-212-338-2400 (25023)
} 


\section{Giriş}

Tarihte kullanılan ilk yelkenli örnekleri, birçok kalın kirișten oluşan ve ortalarına dört köşe seren yelkenin kullanıldığı teknelerdir. Norveç'li bilim insanı Thor Heyerdahl ve arkadaşları Büyük okyanusu Balsa ağacından yapılmış olan Kon-Tiki adı verilen tekne ile aşmışlardır. Bugün Kon-Tiki Oslo'da kendisiyle aynı adı taşıyan müzede sergilenmektedir. Bilinen en eski gemi, M.Ö. 1960-3908 tarihinde firavun Keops'un cenaze töreni için yapılan, $40 \mathrm{~m}$ uzunluğunda, en büyüğü $23 \mathrm{~m}$ uzunluğunda 600 ayrı kereste parçasından oluşan teknedir (Özdemir, 2015).

Geçmişten günümüze yapılmış olan gemiler ve gezinti teknelerinin bazı kısımları ya da tamamı ağaç malzemeden yapılmış ve yapılmaya devam etmektedir (Odabaşı, 2011). Bu yüzdendir ki su taşıtları yapımında hafifliği ve kolay işlenebilirliğiyle tercih sebebi olan ağaç malzeme, kullanılacak olan yere göre çeşitli tür seçeneklerinin de olmasıyla tekne yapımı için idealdir. Tekne yapımı için oldukça avantajlı bir yapıya sahip olan ahşap malzeme suda kalma zamanı göz önüne alındığında canlı bir yapıya sahip olması nedeniyle çeşitli olumsuz durumlar da oluşabilmektedir. $\mathrm{Bu}$ olumsuzluklar; fouling ve biyofilm oluşumu gibi tekne ömrünü azaltan faktörlerdir.

Ahşap malzemenin kullanılacağı yere göre işlenmesi esnasında uygulanacak bazı tedbirler malzemenin kullanım ömrü açısından hayati önem taşımaktadır. $\mathrm{Bu}$ önlemler; uygun ağaç seçimi, doğru yönde işleme, uygun kurutma yöntemi, uygun emprenye yöntemleri gibi seçeneklerdir.

Bakteriler, mayalar, küfler biyofilm ve fouling oluşumlarının temelini oluşturur, ilk zemini hazırlar ve canlılık zincirinin başlangıcını oluştururlar. Biyofilmleri meydana getiren mikroorganizmalar çok çeşitli mikrobiyal popülasyonlardan oluşmaktadır. Bakteriler, algler, protozoonlar (Rotiferler, Nematodlar) biyofilmlerden genel olarak sorumlu organizmalardır. Bunlardan bazıları biyolojik parçalanmaya yol açmaktadır. Örneğin filamentli algler ve 3 aktinomisetler yüzey filmine penetre olup gelişerek yüzeyin zarar görmesine yol açmaktadır. Fototrofik organizmalardan algler ve siyanobakteriler organik besin kaynağına ihtiyaç duymadan biyofilm oluşturmaktadır (Gaylarde vd., 2011).

Gemilerin yakıt tüketimleri suyla temas ettikleri yüzeylerdeki dirence bağlı olarak değişmekte performanslarını etkilemektedir. Gemi direncinin aza indirilmesi hem mühendisler hem de gemi sahipleri için önem arz eden bir konudur. Yakıt tüketiminin azaltılması gemi direncinin azalmasına bağlıdır böylece emisyon da azalmaktadır. Bu durum çevre korunması açısından da büyük önem taşımaktadır. Gemi sürtünme direncinin azaltılması için yüzey özelliklerinin iyileștirilmesi, fiziksel ve biyolojik pürüzlülüğün giderilmesi uygun görülmektedir. Fouling diğer birçok etmene bağlı olmakla birlikte geminin suda kalma gün sayısına bağlı olarak sürekli artmakta bu durum da direnci büyük oranda yükseltmektedir (Demirel, 2012). Bir balık patojen bakteri olan Yersinia ruckeri'nin iki suşu, balık çiftliklerinde yaygın olarak bulunan dört materyal olan ahşap, beton, polivinilklorür (PVC) ve fiberglas üzerine yapışma kabiliyetine göre karakterize edilir. Yapışma, bakteri ve destek hidrofobiklikleri ile yüzey pürüzlülüğü arasındaki ilişkiler araştırılmıştır. Sonucunda $Y$. ruckeri ise güçlü hidrofiliktir yani bir molekülün hidrojen bağları kurarak suya bağlanabilme özelliğidir. Referansa klyasla daha yüksek bir yapışma kabiliyeti sergilemiştir. İki suş için, destek maddesinin pürüzlülük genliği ile yapışma kabiliyeti arasında güçlü bir korelasyon gözlemlenmiștir (Coquet vd., 2002).

Fouling (kirlenme), katı yüzeyler üzerinde istenmeyen malzeme birikmesidir. Söz konusu materyaller canlı organizmalar tarafından (biyofouling: biyolojik kirlenme) ya da cansız maddelerden (inorganik veya organik) oluşabilir. Zamanla biyofouling gelişir ve geniş alana yayılır. Fouling oluşumunda en etkili organizma Mytilus edulis adında bir midye türüdür. Midyeler zamanla çoğalarak ahşap tekne tabanında ağırtahribe neden olmaktadır (Macleod vd., 2016). Biyofilm, hücrelerin birbirine ve/ya da bulundukları yüzeye yapıştıkları bir mikroorganizma kümesi olup birbirine bağlı bu hücreler tarafından üretilen hücre dışı polimerikbir maddenin (EPS) içine gömülü oldukları yapıdır. Biyofilm EPS'si DNA, proteinler ve polisakkaritlerden oluşan polimerik bir oluşumdur. Biyofilmler canlı veya canlı olmayan yüzeylerde oluşabilir (Hentzer vd., 2003). Günümüzde ahşap teknelerde bu doğal biyolojik kirlenmelerin önüne geçmek için biyofouling ve biyofilm yapılarının detaylıca araştırılması planlanmaktadır.

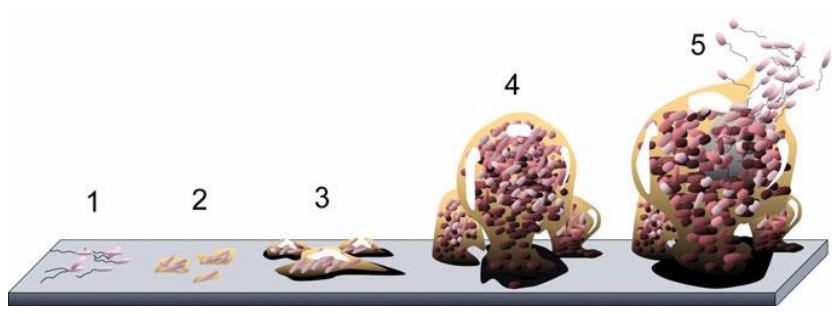

Şekil 1. Biyofilm gelişmesinin beş aşaması; Aşama 1: Planktonik (yüzen yüzen) bakteriler biyomateryal yüzeyine yapışırlar, Așama 2: Hücreler toplanır, mikro koloniler oluşturur ve ekstraselüler polimerik maddeler (EPS), yani slime dıșarı atılır ve bağlanma geri döndürülemez hale gelir, Aşama 3: Biyofilm oluşur, olgunlaşır ve hücreler çok katmanlı kümeler oluşturur, Aşama 4: Üç boyutlu büyüme ve konakçı savunma mekanizmalarına ve antibiyotiklere karşı koruma sağlayarak biyofilmin daha da olgunlaşması, Așama 5: Biyofilm, kritik bir kütleye ulașır ve diğer yüzeylere kolonize olmaya hazır, planktonik bakterileri dağıtır (Unosson, 2015). 


\section{Tekne Yapımında Kullanılan Ağaç Malzeme ve Özellikleri}

Ağaç malzeme elementer bileşenler olarak C (karbon), $\mathrm{H}$ (hidrojen) ve $\mathrm{O}$ (oksijen)'den oluşmakta çok az miktarda ise (<\% 1) $\mathrm{N}$ (azot) ve kül içermektedir. Odunun kimyasal bileșenleri selüloz, hemiselüloz ve lignin'dir. Bunlara ek olarak odunda ekstraktif maddeler diye tabir edilen; tanenler, reçineler, uçucu yağlar, nişasta, sakız, alkoloidler gibi organik ve inorganik maddeler bulunmaktadır. Odunlaşma lignin maddesinin hücre çeperi tabakalarına ve hücreler arasına girmesiyle meydana gelir. Kolaylıkla okside olmasına karșın lignin basınca karșı, selüloz eğilme ve çekmeye karşı dirence sahiptir. Ağaç malzeme dayanıklılığı sebebiyle kimyasal madde depo ve tanklarının yapımında tercih edilebilir. Odun gözenekli bir yapıya sahiptir ve higroskopik özellik gösterir. Kurutmada tam kuru hale getirilmediği sürece bünyesinde sürekli su bulunduran odun uzun süre suda kalırsa bütün boşlukları su ile dolar. Ağaç malzemenin mantar, hayvansal ve çevresel tehditlerden korunması için yapısındaki boşlukların kimyasal maddelerle doldurulması işlemine emprenye denir. Ağaç malzemenin kullanım yerine göre değişen emprenye maddeleri mevcuttur. Örneğin, yağlı emprenye maddeleri sslak mekanlarda kullanılacak ağaç malzemedeki suyun hareketini yavaşlatıp mantarın gelişimini önlemek için kullanılır. İğne yapraklı ağaçların anatomik özellikleri pek uygun olmadığı için emprenye edilmeleri güçtür (Örs ve Keskin, 2001).

Gemi yapımında kullanılan ağaç malzeme; geminin yapım aşamasında destek olarak yardımcı malzeme şeklinde, büyük gemilerin yapımında ve küçük deniz taşıtlarının yapımında kullanılan malzeme olarak üç başlık altında incelenebilir. Tersanelerde ağaç, gemi teknesine iskele görevi görmektedir. Ayrıca teknenin denize ulaştırılmasına yardımcı kızakların yapımında Pinus palustris (Uzun ibreli çam) ve Meşe (Quercus spp.) ağaçları sertlik, yüksek aşınma direnci özellikleri ve esneklikleri sayesinde tercih edilmektedirler. Günümüzde kutuplarda kullanılan büyük gemiler basınca karşı esnek olması gerektiği için ağaç malzemeden yapılmaktadır. Büyük gemi yapımında güverte yapımında kullanılan ağaç malzeme direnç özellikleri yüksek, hava şartlarından uzun süre etkilenmeyen türde olmalıdır. Güverte döşemelerinde Meșe'den daha dayanıklı olan yabancı ağaç cinslerinden Tectona grandis (Tik) ağacı kullanılmaktadır. Tik ağacı odunu kolay işlenmesi, çalışmasının az oluşu, az miktarda tanen içermesi ve dayanıklılığı sebebiyle güverte yapımında tercih edilmektedir. Güverte döşemelerinde tercih edilen ikinci ağaç türü ise fazla reçine içeren, esnek ve rutubete karşı dayanıklı $P$. palustris'tir (aves.ktu.edu.tr).

Geminin içindeki zemin katlarında ve döșemelerinde ağacın kullanılması: Bu hususta Çam, Ladin, Göknar,
Kayın gibi bildiğimiz yapı ağaçları kullanılır. Buralarda odunda aranan en önemli özellik dirençtir. Gemi pervane mil yatakları yapımında ise basınç ve aşınmalara karşı dirençli olan en sert ve en ağır yabancı ağaç türü 'Pelesenk' (Guaijacum oficinale)'dir. Küçük gemilerin esas kısımlarının yapımında en çok tercih edilen ağaç cinsleri Beyaz Meşe (Quercus spp.), Kestane (Castanea spp.), Dişbudak (Fraxinus spp.) ve Kızılçam (Pinus brutia L.)'dır (Bozkurt ve Göker, 1981).

Tekne yapımında kullanılacak olan ahşap malzeme kullanımı sırasında \%20 nem oranına sahip olmalıdır. Kurutma ișleminin iyi yapılmıș olması ve mantar, böcek, bakteri, kurtçuk gibi zararlı etmenlerden arındırılmış olması gerekmektedir. Kullanılacak deniz tipi kontrplaklarda kurutma ve presleme sırasında uygulanan yüksek sıcaklıklar böcek ve kurtçukların canlı kalma ihtimallerini ortadan kaldıracaktır. Aynı ortam şartlarında kullanılan solid ahşap malzemeye nispeten, deniz tipi kontrplak; düşük neme sahip olması nedeniyle küflenme eğilimi azdır ve dayanıklılığı fazladır. Tekne yapımında kullanılan ağaçlardan dayanıklılık bakımından en ön sırada gelenler; Afrika orijinli Doussie (Afzelia spp) ve Makore (Tieghemella spp), Asya orijinli Tik ağacıdır. $\mathrm{Bu}$ alanda kullanılacak ahșap tekne yapı elemanları göz önünde bulundurulduğunda en önde gelen ağaç türleri, omurga, su hattı altındaki ve üstündeki kısımlara en uygun olanlar Doussie ve Tik ağaçlarıdır, ardından bunları Meșe (Quercus spp.) ve Kestane takip etmektedir. Ahşapların birleştirilmesinde suya dayanıklı olan resorsinik ya da fenolik yapıștırıcılar kullanılacaktır. Kontrplakların kenarları nem girișini önlemek için boya, yapıştırıcı veya uygun bir ürünle kaplanmaktadır (Türk Loydu, 2014).

\section{Ahşap Teknelerde Biyofilm Oluşturan Mikroorganizmalar ve Etkileri}

Biyofilm; mikroorganizmalar tarafından oluşturulan, mikroorganizmaların herhangi bir yüzeye veya birbirlerine yapışmalarını sağlayan ve büyüme oranları ile gen transkripsiyonuna bağlı olarak farklı fenotip oluşturan, mikroorganizmaların içinde gömülü olarak bulunduğu ekstraselüler polimerik maddeden olușmuș matrikslerdir (Donlan ve Costerton, 2002; Şimşek ve Bulut, 2012). Delille vd. (2007)'de mikroorganizmalarda biyofilm tabakasının varlığından ve biyofilmin ilk katmanının germanyum kristallerinden oluștuğunu belirtmişlerdir. Yapılan araştırmalar üzerinden gidildiğinde canlılık katmanın olduğu yerde biyofilm varlığından söz edilebilmektedir. Biyofilm, hücrelerin birbirine ve bulundukları yüzeye yapıştıkları bir mikroorganizma kümesi olup birbirine bağlı bu hücreler genellikle kendilerince üretilen hücre dışı polimerik bir maddenin içindedirler.

Fouling ve biyofilm olușumunun ilk așamasında rol oynayan denizde bulunan patojenlerden Escherichia 
coli, Clostridium perfiringens, Shigella spp., Staphylococcus aureus, Vibrio anguillarum, Vibrio parahaemolyticus, Vibrio alginolyticus, Pseudomonas fluorescens, Aeromonas hydrophila, Yersinia ruckeri, Edwardsiella tarda, salmonarium, Piscirickettsia salmonisPhoto: Renibacterium salmonrium, Streptococcus iniae, Mycobacterium marinum, Flavobacterium columnare, Epistylis, Trichodina, Glossatella, Ichthyobodo necator, Myxobolus cerebralis, Ichthyophthirius multifiliis, Cryptocaryon irritans, Ichthyobodo necator, Saprolegnia sp. Nematodes, Cestodes, Trematodes, Pentastomes, Arthropods, Acanthocephalus minor, Monogenean trematodes, Ligula intestinalis, Parasitic copepods, Lernaeocera branchialis sadece bazılarıdır. Biyofilm olușumunun bir diğer açıklaması bakterilerin kötü ortam şartlarında hayata kalabilmek için geliştirdikleri bir strateji şeklindedir (Hentzer vd., 2003). Bütün bu mikroorganizmalar ve daha fazlası bu stratejiyle biyofilm oluşumunu gemi yüzeyine bırakır. Daha sonra makro deniz canlılarıyla birlikte fouling oluşur. Canlıların bu etkisiyle ahşap gemilerde aşınma ve korozyon kaçınılmazdır. Denizel biyofilmler, sucul ortamda her yerde gözlenebilen mikrobiyal oluşumlardır (Killea, 2014). Gün ve Ekinci, 2009'da LapA yüzey proteini aracılı̆̆ıyla mikroorganizmalarda biyofilm oluşumunda dönüşümsüz, tutunma aşamasında ise destekleme fonksiyonlarını oluşturduğunu bildirmişlerdir.

Altuğ vd. (2007), deniz ortamında kullanılan materyallerden olan ahşap, galvaniz, saç, paslanmaz çelik, pamuk halat, cam ve alüminyum materyalleri üzerinde oluşan bakteriyel biyofilm tabakasında bulunan mezofilik aerobik heterotrofik bakteri düzeylerini araştırmışlardır. Laboratuvar ortamında kurulan cam düzenek deniz suyu ile doldurulmuş, invertöre bağlı olarak havalandırması kontrol edilmiş ve içine eşit ebatlarda farklı materyaller yerleştirilmiştir. Deniz suyunda başlangıçtaki bakteri düzeyini membran filtrasyon metoduyla tespit etmişler ve 48 saat arayla ölçümleri sürdürmüşlerdir. 12. günün sonunda biyofilm tabakasını gözlemlemişlerdir. Aseptik koşullarda materyaller üzerinden $1 \mathrm{~cm}^{2}$ 'lik alandan alınan kazıntı örneklerini homojenize ederek Marine ve Nutrient Agar'a ekmişlerdir. Agarlarda mesofilik heterotrofik aerobik bakteri düzeylerini belirlemişlerdir. Denemeler 29 gün boyunca 48 saatte bir tekrarlanarak bakteri düzeylerinin materyale bağlı olarak tutunma oranlarını karșılaștırmışlardır. En yüksek bakteri düzeyi pamuk halatta gözlenirken bunu ahşap, alüminyum, saç, cam, paslanmaz çelik ve galvanizin takip ettiğini belirtmişlerdir. Materyallerde tespit edilen bakteri düzeyinin deniz suyundakinden yüksek olduğunu gözlemlemişlerdir.

\subsection{Ahşap Gemi Gövdelerinde Denizel Fouling'den Korunma Süreci}

Mikroorganizmaların tutunma kabiliyeti ve büyüme oranları; boya kaplamasının yapısına bağlıdır. Bu da boya substratının seçimini, dolayısıyla çevresel davranışlarını etkilemektedir (Gaylarde vd., 2011). Bunun yanı sıra, son yıllarda gemi yüzeylerine uygulanan antifouling boya uygulamaları, yalnızca foulinge maruz kalacak denizle temas halindeki yüzeyleri, foulingten önlemekle kalmazken; biyositlerin denize yayılımı ile ilgili geliştirilen mevzuata ve yönetmeliğe de uyum sağlamak zorundadır (Omuzbüken, 2016).

Günümüzde antifouling boyalar ve dezenfektanlar denizel foulingi engellemek adına halen yaygın olarak kullanılmaktadır. Bu kimyasalların etki mekanizması, kullanılan biyosit çeşidine bağlı değişkenlik göstermektedir. Potansiyel hedef bölgeleri gram pozitif ya da gram negatif bakterilerin hücre duvarları, sitoplazmik membranları, fonksiyonel ve yapısal proteinleri, DNA, RNA ve diğer sitozolik bileşiklere karşı olduğu bilinmektedir. Biyositlerin bu uygulama kapasitelerine rağmen, bazı mikroorganizmalar hayatta kalmaya devam edebilmektedir. Mikroorganizmaların antifouling ajanlara karşı olan bu direnci yüzeyde biyofilm yapısı olușturmaları ile ilişskilendirilmektedir (Bridier vd., 2011). Gemi gövdelerini denizel foulingden koruma ihtiyacı, insanların gemiyi bir hareket aracı olarak kullanmaya başlamalarından beri var olmuştur. Tablo 1.'de görülen antifouling ürünler, örneğin; balmumu, asfalt ve katran gibi doğal ürünlerin çok eski zamanlardan 19. yüzyıl ortalarına kadar kullanılmakta olduğu bilinmektedir (Almeida vd., 2007; Omuzbüken, 2016).

Antifouling ürün olarak geçmiște; metalik bileșikler, kireç, cıva, arsenik kullanılmıştır. Son zamanlarda ise uzun ömürlü olmasıyla (Tributyltin) TBT tercih edilmiștir (Haak, 1996). TBT'nin deniz ekosistemine verdiği zararlı etkiler göz önünde bulundurularak kalay içermeyen alternatif Antifouling ürünler geliştirilmiştir (Okay, 2004). 
Tablo 1. Tarih öncesinden 19. yy ortalarına kadar kullanılan antifouling ürünler (Almeida vd., 2007; Omuzbüken, 2016).

\begin{tabular}{|c|c|c|c|}
\hline $\begin{array}{l}\text { Kullanan } \\
\text { Uygarlık }\end{array}$ & $\begin{array}{l}\text { Uygulama } \\
\text { Dönemi }\end{array}$ & Antifouling Ürün & $\begin{array}{c}\text { Gövde } \\
\text { Tipi }\end{array}$ \\
\hline $\begin{array}{l}\text { Tarih öncesi } \\
\text { topluluklar }\end{array}$ & $\begin{array}{c}\text { Tarih öncesi } \\
\text { dönem }\end{array}$ & $\begin{array}{l}\text { Balmumu, katran ve } \\
\text { asfalt }\end{array}$ & Ahşap \\
\hline $\begin{array}{l}\text { Fenikeliler, } \\
\text { Kartacalılar }\end{array}$ & M.0̈. 700 & $\begin{array}{c}\text { Zift ve olasılıkla bakır } \\
\text { kaplama }\end{array}$ & \\
\hline Fenikeliler & $\begin{array}{l}\text { M.Ö. } 700 \\
\text { M.Ö. } 500\end{array}$ & $\begin{array}{c}\text { Kurşun kılıf ve don } \\
\text { yağı } \\
\text { Yağ ile karıșık arsenik } \\
\text { ve kükürt kaplamalar }\end{array}$ & \\
\hline Yunanlılar & M.0̈. 300 & $\begin{array}{l}\text { Balmumu, katran ve } \\
\text { kurşun kaplama }\end{array}$ & \\
\hline $\begin{array}{l}\text { Romalılar, } \\
\text { Yunanlılar }\end{array}$ & $\begin{array}{l}\text { M.Ö. } 200 \text { - M.S. } \\
45\end{array}$ & $\begin{array}{l}\text { Bakır çivi kullanımı ve } \\
\text { kurşun kaplama }\end{array}$ & \\
\hline Vikingler & M.S. 10 & Sızdırmazlık katranı & \\
\hline $\begin{array}{c}\text { Çeşitli } \\
\text { Uygarlıklar }\end{array}$ & M.S. $45-125$ & $\begin{array}{c}\text { Yosun, balçık ve zift } \\
\text { kazıntısı }\end{array}$ & \\
\hline $\begin{array}{c}\text { Çeşitli } \\
\text { Uygarlıklar }\end{array}$ & 13. - 15. yy'lar & $\begin{array}{l}\text { Zift, yağ, reçine veya } \\
\text { don yağı karışımları }\end{array}$ & \\
\hline $\begin{array}{c}\text { Çeşitli } \\
\text { Uygarlıklar }\end{array}$ & $\begin{array}{c}1618-1625 \\
18 . y y\end{array}$ & $\begin{array}{c}\text { Bakır, olasılıkla } \\
\text { çimento, demir tozu ve } \\
\text { bakır bileșiği (sülfür) } \\
\text { veya arsenik cevheri } \\
\text { karışımı } \\
\text { Hayvan kılından bir } \\
\text { katman üzerinde } \\
\text { yüzeysel ahșap } \\
\text { kaplama Başları } \\
\text { metalik kaplama türü } \\
\text { ile oluşturulan çok } \\
\text { sayıda metalik } \\
\text { çivilerle; katran, yağ, } \\
\text { kükürt ve zift } \\
\text { karışımları ile } \\
\text { düzenlenmiş ahşap } \\
\text { kaplama }\end{array}$ & \\
\hline $\begin{array}{c}\text { Çeşitli } \\
\text { Uygarlıklar } \\
\text { Íngilizler }\end{array}$ & 1758 & $\begin{array}{c}\text { Bakır kaplamanın, } \\
\text { demir çivi ile galvanik } \\
\text { korozyona terk } \\
\text { edilmesi }\end{array}$ & \\
\hline İngilizler & 1786 & $\begin{array}{l}\text { Bakır ve çinko alaşımı } \\
\text { çivi kullanılarak bakır } \\
\text { kaplama }\end{array}$ & \\
\hline İngilizler & 19.yy öncesi & $\begin{array}{l}\text { Sir Humphrey Davy, } \\
\text { bakır korozyon } \\
\text { sürecini inceledikten } \\
\text { sonra; deniz suyunda } \\
\text { bakır çözünmesinin } \\
\text { foulingi önlediğini } \\
\text { göstermiştir. } \\
\end{array}$ & $\begin{array}{l}\text { Ahşap } \\
\text { ya da } \\
\text { çelik }\end{array}$ \\
\hline $\begin{array}{c}\text { Çeşitli } \\
\text { Uygarlıklar }\end{array}$ & $\begin{array}{c}1758-1816 \\
1862\end{array}$ & $\begin{array}{c}\text { Bakır kaplama ile } \\
\text { desteklenen ahşap } \\
\text { kaplama ve ardından } \\
\text { çinko, kurşun, nikel, } \\
\text { arsenik, galvanize çelik } \\
\text { ve antimon, çinko ve } \\
\text { kalay alaşımı kaplama. } \\
\text { Desteklenmiş metalik } \\
\text { olmayan kaplama } \\
\text { (kauçuk, ebonit, } \\
\text { mantar, emaye, vb) } \\
\text { Bakır kaplama ile } \\
\text { kaplanmış ahşap } \\
\text { kaplama (maliyet } \\
\text { nedeniyle terk } \\
\text { edilmiștir) } \\
\end{array}$ & \\
\hline $\begin{array}{c}\text { Çeşitli } \\
\text { Uygarlıklar }\end{array}$ & 19. yy ortaları & $\begin{array}{c}\text { Zehirli bir madde } \\
\text { içeren boyanın (bakır, } \\
\text { arsenik ya da civa } \\
\text { oksit); polimerik bir } \\
\text { bağlayıcı içinde } \\
\text { dağıtılması (keten } \\
\text { tohumu yağı, şelat, } \\
\text { kolofan) } \\
\end{array}$ & \\
\hline
\end{tabular}

\section{Sonuç ve Tartışma}

Fouling oluşturan mikroorganizmalar hem maliyet açısından hem de sağlık açısından tehdit unsurlarıdır. Ahșap gemilerin güvenliği, gemi yapımında görevli personel, kıyı kentlerde yaşayan insanlar için çok önemlidir. Sağlık başlığında ele alındığında gemilerde fouling oluşumunun önüne derhal geçilmeli ve gerekli tedbirlerin alınması gerekmektedir. Bu bağlamda anti fouling boya kulanımıyla Tributyltin (TBT)'nin çevre ve deniz canlılarının önüne geçilmiştir.

Biyofilm ve foulingin doğa için herhangi bir faydası bulunmamaktadır. Biyofilm ve fouling gerek insan sağlığı gerek sucul ortamlarda ispatlanan ciddi hasarlara neden olmaktadır ifadesinden yola çıkılarak bu iki doğa olayı engellenmek durumundadır. Bu iki olayın önüne geçilerek ahşap teknelerin ömrü ciddi oranda uzatılabilmektedir.

Bu çalışmada daha spesifik olarak ahşap teknelerde de suyla temas halinde sucul ekosistemde bulunan mikroorganizmalar anında tutunmakta, biyofilm oluşturmakta, biyofilmi takiben virülens faktörlerini ortaya çıkarmakta ve ahşabın aşınmasını hızlandırmaktadır. Biyofilm mikroorganizma temelinde oluştuğu için hem insan sağlı̆̆ını ciddi oranda tehdit etmektedir hem de gemi malzemesini tahrip ederek mail anlamda zarar vermektedir. Biyofilm ve zararlı etkilerinin görülmemesi için bakterinin hiç ürememesi gerekmektedir. $\mathrm{Bu}$ amaçla gemi yapımında seçilecek ağacın dayanıklılığı, aşınma süresinin uzunluğu gibi faktörler önem arz etmektedir. Çalışmada; ahşap gemi yüzeyinde oluşan biyofilm ve fouling tehdidine değinilmiş, önlem alınması hususunda tavsiyelerde bulunulmuştur.

Teknenin suyla temas eden yüzeyi teknenin hiz performansı açısından önem arz etmektedir. $\mathrm{Bu}$ yüzden tekne yüzeylerinde oluşan mikroorganizmaların çeşitleri, oluşma şartları ve özellikleri konusuna değinilerek tekne endüstrisine farklı bir bakış açısı kazandıracağı düşünülmektedir.

\section{Conflict of Interest / Çıkar Çatışması}

Yazarlar tarafından herhangi bir çıkar çatışması beyan edilmemiştir.

No conflict of interest was declared by the authors.

\section{Kaynaklar}

Almeida, E., Diamantino, T.C., De Sousa, O., 2007. Marine paints: The particular Case of Antifouling Paints. Progress in Organic Coatings, 59, 2-20.

Altuğ, G., Çardak, M., Çiftçi, P.S., Gürün, S., 2007. Farklı Materyallerde Oluşan Bakteriyel Biyofilm Tabakasından İzole Edilen Aerobik Heterotrofik 
Bakteri Düzeyleri, Ulusal Su Günleri Antalya, Türkiye, 16-18 Mayıs, 561-566.

Aves.ktu.edu.tr.2018. aves.ktu.edu.tr/ImageOfByte.aspx?Resim=8\&SSN $\mathrm{O}=4 \& \mathrm{USER}=3996(25.08 .2018)$.

Bozkurt, Y., Göker, Y., 1981. Orman Ürünlerinden Faydalanma Ders Kitabı. İstanbul Üniversitesi Yayın No: 2840, Orman Fakültesi Yayın No: 297, 239-241.

Bridier, A., Briandet, R., Thomas, V., DuboisBrissonnet, F., 2011. Resistance of Bacterial Biofilms to Disinfectants: A review. Biofouling, 27(9), 1017-1032.

Coquet, L., Cosette, P., Junter, G. A., Beucher, E., Saiter, J. M., Jouenne, T., 2002. Adhesion of Yersinia Ruckeri to Fish Farm Materials: Influence of Cell and Material Surface Properties. Colloids and Surfaces B: Biointerfaces, 26(4), 373-378.

Delille, A., Quile`s, F., Humbert, F., 2007. In Situ Monitoring of the Nascent Pseudomonas Fluorescens Biofilm Response to Variations in the Dissolved Organic Carbon Level in Low-Nutrient Water by Attenuated Total Reflectance-Fourier Transform Infrared Spectroscopy. Applied and Environmental Microbiology, 73(18). 5782-5788.

Demirel, Y.K., 2012. Yüzey Kirliliğinin Gemi Direnci Üzerindeki Etkisinin İncelenmesi. YL Tezi, İstanbul Teknik Üniversitesi, Fen Bilimleri Enstitüsü, Gemi İnşaatı ve Gemi Makineleri Anabilim Dalı, İstanbul.

Donlan, M.R., Costerton, J.W., 2002. Biofilms: Survival Mechanisms of Clinically Relevant Microorganisms. Clinical Microbiology Reviews, 15(2), 167-93.

Gaylarde, C., Morton, L.H.G., Loh, K. ve Shirakawa, M.A., 2011. Biodeterioration of External Architectural Paint Films: A Review. International Biodeterioration \& Biodegradation, 65(8), 11891198.

Gün, İ., Ekinci, F.Y., 2009. Biyofilmler: Yüzeylerdeki Mikrobiyal Yaşam. Gıda, Derleme/Review, 34(3), 165-173.

Haak, P.W., 1996. Antifouling Systems, current status and developments. In: The Present Status of TBTCopolymer Antifouling Paints, Proceedings of the International Symposium on Antifouling Paints for Ocean-going Vessels, The Hague, February 21.

Hentzer, M., Eberl, L., Nielsen, J., Givskov, M., 2003. Quorum Sensing A Novel Target for the Treatment of Biofilm Infections. Drug Development, 17(4), 241-250.
Killea, L.M., 2014. Microbial Community Composition of Marine Biofilms in a Northern Temperate. YL Tezi, Rhode Island Üniversitesi, Kingston, ABD.

Macleoda, A.K., Stanley, M.S., Dayb, J.G. ve Cook, E.J., 2016. Biofouling Community Composition Across A Range of Environmental Conditions and Geographical Locations Suitable for Floating Marine Renewable Energy Generation. Biofouling: The Journal of Bioadhesion and Biofilm Research, 32(3), 261-76.

Odabaşı, A.Y., İstanbul Teknik Üniversitesi Gemi İnşaatı ve Deniz Bilimleri Fakültesi Gemi İnşaatı ve Gemi Makinaları Bölümü 2010-2011 Güz Yarıyılı Ders Notları, Düzenleyen Y. Doç. Dr. Şebnem Helvacioğlu, Müh. Nalan Erol, (143), 1-187.

Okay, O. S., 2004. Antifouling İçeren Gemi Boyalarının Uluslararası Kurallar Çerçevesinde Kirletici Etkilerinin İncelenmesi. Gemi Mühendisliği ve Sanayimiz Sempozyumu, 24-25 Aralık, 168-178.

Omuzbüken, B., 2016. Denizel Biyofilm Bakterilerinin Biyositlere ve Ağır Metallere Karşı Toleranslarının Araștırılması. YL Tezi, Dokuz Eylül Üniversitesi, İzmir.

Örs, Y., Keskin, H., 2001. Ağaç Malzeme Bilgisi. Atlas Yayın Dağıtım Ltd. Şti., Yayın No: 02, pp: 47, 48, 51, 52, 141, Ankara.

Özdemir, Ü., 2015. Tarihte Türk Denizcilik Faaliyetleri ve Günümüz Limanlarının Gelişim Sürecine Olan Etkisinin İncelenmesi, SOBİAD, Ordu, Türk Deniz Ticareti Sempozyumu VII. Karadeniz Limanları, Sempozyumu, 29 Nisan-01 Mayıs 2015, 421-441.

Şimşek, N., Bulut, E.T., 2012. Biyofilm ve Endodonti: Bölüm 1 Biofilm and Endodontics: Part 1, Derleme. İnönü Üniversitesi Sağlık Bilimleri Dergisi, 2, 1-5.

Türk Loydu - Boyları 24m'den Küçük Ahşap Yolcu Teknelerinin Yapımı ve Klaslanmasına İlişkin Kurallar - 2014. Bölüm 2 - Tekne Konstrüksiyonu Ahşap Tekneler. pp. 2-2,2-3,2-4,2-5.

Unosson, E., 2015. Antibacterial Strategies for Titanium Biomaterials. Digital Compre hensive Summaries of Uppsala Dissertations from the Faculty of Science and Technology 1250, Doktora Tezi, UPPSALA Üniversitesi, İsveç. 